\title{
PENERAPAN METODE OVERALL EQUIPMENT EFFECTIVENESS (OEE) DAN FAULT TREE ANALYSIS (FTA) UNTUK MENGUKUR EFEKTIFITAS MESIN RENG
}

\author{
Hery Suliantoro, Novie Susanto*), Heru Prastawa, Iyain Sihombing, Anita M. \\ Program Studi Teknik Industri, Fakultas Teknik, Universitas Diponegoro \\ Jl. Prof. H. Soedarto, S.H, Tembalang, Semarang, Indonesia 50275
}

(Received: April 20, 2016/ Accepted: July 17, 2017)

\begin{abstract}
Abstrak
Mesin reng digunakan untuk memproduksi atap baja ringan jenis reng $V$ belum sepenuhnya bekerja secara efektif. Hal ini ditunjukkan dengan adanya downtime, penurunan kecepatan produksi mesin, dan produk-produk yang tidak sesuai standard yang telah ditetapkan. Penelitian ini bertujuan untuk mengukur dan mengetahui tingkat efektivitas mesin reng dengan menggunakan metode Overall Equipment Effectiveness (OEE), mengidentifikasi faktor penyebab six big losses dengan menggunakan Fault Tree Analysis (FTA), dan memberikan usulan perbaikan untuk meningkatkan tingkat efektivitas mesin. Dari hasil penelitian, OEE mesin reng mencapai rata-rata 57,55\%, dan masih berada di bawah nilai OEE ideal (85\%). Usulan perbaikan yang direkomendasikan meliputi eliminasi six big losses, mengembangkan program pemeliharaan, dan memberikan pelatihan untuk meningkatkan kemampuan maintenance dan operasional.
\end{abstract}

Kata kunci: Overall Equipment Effectiveness (OEE), Six Big Losses, Fault Tree Analysis (FTA)

\begin{abstract}
The reng machine, which is used to produce lightweight steel roof with a kind $V$ reng, has not fully worked effectively. This is indicated by the presence of downtime, speed losses, and produce products that are not according to standards that have been determined. This study aims to measure and determine the level of effectiveness of reng machine using Overall Equipment Effectiveness (OEE) method, identify factors that cause six big losses by using Fault Tree Analysis (FTA), and proposes improvements to increase the effectiveness of the machine. The result of research, OEE of reng machine reached an average of $57.55 \%$, and still was below the ideal OEE (85\%). Proposed improvements that recommended include the elimination of six big losses, develop a maintenance program, and provide training to improve the ability of maintenance and operations.
\end{abstract}

Keywords: Overall Equipment Effectiveness (OEE), Six Big Losses, Fault Tree Analysis (FTA)

\section{Pendahuluan}

Sebuah mesin bekerja secara efektif apabila mampu melakukan proses produksi selama jangka waktu yang telah disediakan tanpa mengalami gangguan, bekerja sesuai dengan kecepatan yang ditentukan, dan menghasilkan produk-produk yang baik (sesuai standard yang telah ditetapkan). Supervisi bisa dilakukan melalui berbagai cara salah satunya melalui menerapan Total Productive Maintenance (TPM) (Almeanazel, 2010; Limantoro \& Felecia, 2006). Namun, sebuah mesin yang mengalami downtime, speed losses, atau menghasilkan produk yang cacat menunjukkan bahwa mesin tidak bekerja secara efektif (Nakajima, 1988).

\footnotetext{
*) Penulis Korespondensi.

email: nophie.susanto@gmail.com
}

Overall Equipment Effectiveness (OEE) merupakan metode yang dapat digunakan untuk mengukur efektivitas mesin yang didasarkan pada pengukuran tiga rasio utama, yaitu : availability, performance efficiency, dan rate of quality (Saiful, et.al., 2014). Dengan mengetahui nilai efektivitas mesin, maka dapat dilihat seberapa besar kerugian yang mempengaruhi efektivitas mesin yang dikenal dengan six big losses peralatan.

Penelitian ini mengambil kasus produksi atap baja ringan pada CV. Ali Griya merupakan sebuah usaha kecil menengah (UKM) yang bergerak dalam memproduksi atap baja ringan di daerah Banyumanik, Semarang. Atap baja ringan yang diproduksi terdiri dari tiga jenis yaitu reng $\mathrm{V}$, canal $\mathrm{C}$, dan spandek. Berdasarkan tujuan operasinya dalam hubungannya dengan pemenuhan kebutuhan konsumen, diterapkan sistem produksi Make to Stock (MTS) di mana atap baja ringan yang diproduksi akan ditempatkan sebagai 
persediaan dan selanjutnya akan dikeluarkan jika pesanan konsumen sudah diterima.

Penelitian ini akan difokuskan pada mesin reng yaitu mesin yang digunakan untuk memproduksi atap baja ringan jenis reng $\mathrm{V}$. Baja ringan jenis reng $\mathrm{V}$ adalah produk yang lebih banyak diproduksi dan dipesan dibandingkan dengan produk lainnya, dan berdasarkan data yang dikumpulkan terkait efektivitas mesin reng menunjukkan bahwa mesin ini belum sepenuhnya bekerja secara efektif. Hal ini ditunjukkan dengan adanya data downtime, data penurunan kecepatan mesin, dan data produk yang tidak sesuai spesifikasi.

Untuk itu dilakukan penelitian untuk mengukur tingkat efektivitas mesin reng dengan menggunakan metode Overall Equipment Effectiveness (OEE), menganalisa penyebab six big losses mesin reng dengan menggunakan Fault Tree Analysis (FTA), dan memberikan rekomendasi perbaikan untuk meningkatkan efektivitas mesin reng.

\section{Metode Penelitian}

Penelitian ini terdiri dari 2 (dua) tahapan pengolahan data, yaitu tahapan menghitung tingkat efektivitas mesin reng dengan mengunakan metode overall equipment effectiveness (OEE), dan tahapan menganilis faktor penyebab six big losses mesin reng dengan mengunakan fault tree analysis (FTA).

\section{Overall Equipment Effectiveness (OEE)}

OEE adalah hasil yang dapat dinyatakan sebagai rasio output aktual dari peralatan dibagi dengan output maksimum peralatan di bawah kondisi performa terbaik (Almeanazel, 2010). OEE didasarkan pada pengukuran tiga rasio utama, yaitu: availability $(A)$, performance efficiency $(P E)$, dan rate of quality product (ROQP) (Saiful, et al., 2014).

Availability merupakan suatu rasio yang menggambarkan pemanfaatan waktu yang tersedia untuk kegiatan operasi mesin dan peralatan. Availability merupakan rasio dari operation time, dengan mengeliminasi downtime peralatan terhadap loading time (Saiful, et al., 2014). Maka, formula yang digunakan untuk mengukur availability adalah:

$$
A=\frac{\text { Loading time }- \text { Downtime }}{\text { Loading time }} \times 100 \% \quad \text { (Pers. 1) }
$$

Performance efficiency merupakan suatu ratio yang menggambarkan kemampuan dari peralatan dalam menghasilkan barang. Rasio ini merupakan hasil dari operating speed rate dan net operating rate (Saiful, et al., 2014). Formula pengukuran rasio ini adalah:

$$
P E=\frac{\text { Ideal cycle time } \times \text { Processed amount }}{\text { Operating time }} \times 100 \% \text { (Pers. 2) }
$$

Rate of quality product merupakan suatu rasio yang menggambarkan kemampuan peralatan dalam menghasilkan produk yang sesuai dengan standar (Saiful, et al., 2014). Formula yang digunakan untuk pengukuran rasio ini adalah:

$$
\left.R O Q P=\frac{\text { Processed amount }- \text { Defect amount }}{\text { Processed amount }} \times 100 \% \quad \text { Pers. } 3\right)
$$

Nilai OEE diperoleh dengan mengalikan ketiga rasio utama tersebut (Saiful, et al., 2014). Secara matematis formula pengukuran nilai $\mathrm{OEE}$ adalah:

$$
O E E=A \times P E \times R O Q P \quad \text { (Pers. 4) }
$$

\section{Six Big Losses}

Terdapat enam kerugian peralatan yang menyebabkan rendahnya kinerja dari peralatan yaitu equipment failure (breakdown losses), setup and adjustment losses, idling and minor stoppage losses, reduced speed losses, process defect losses, reduced yield losses (Saiful, et al., 2014).

Breakdown losses yaitu kerusakan mesin/ peralatan yang tiba- tiba atau kerusakan yang tidak diinginkan tentu saja akan menyebabkan kerugian, karena mesin kerusakan mesin akan menyebabkan mesin tidak beroperasi menghasilkan output (Saiful, et al., 2014). Untuk menghitung breakdown losses (BL) digunakan rumus:

$$
B L=\frac{\text { Total breakdown time }}{\text { Loading time }} \times 100 \% \quad \text { (Pers. 5) }
$$

Setup and adjustment losses (SAL) yaitu kerugian karena pemasangan dan penyetelan (Saiful, et al., 2014). Untuk menghitung setup and adjustment losses digunakan rumus:

$$
S A L=\frac{\text { Total setup and adjustment losses }}{\text { Loading time }} \times 100 \% \text { (Pers. 6) }
$$

Idle and minor stoppage losses (IMSL) disebabkan oleh kejadian-kejadian seperti pemberhentian mesin sejenak, kemacetan mesin, dan idle time dari mesin (Saiful, et al., 2014). Untuk menghitung idle and minor stoppage losses digunakan rumus:

$$
I M S L=\frac{\text { Nonproductive time }}{\text { Loading time }} \times 100 \% \quad \text { (Pers. 7) }
$$

Reduced speed losses (RSL) yaitu kerugian karena mesin tidak bekerja optimal (penurunan kecepatan operasi) terjadi jika kecepatan aktual operasi mesin atau peralatan lebih kecil dari kecepatan optimal atau kecepatan mesin yang dirancang (Saiful, et al., 2014). Untuk menghitung reduced speed losses digunakan rumus: 


$$
\begin{aligned}
& R S L \\
& =\frac{\text { Actual processing time }- \text { Ideal processing time }}{\text { Loading time }} \\
& \times 100 \%
\end{aligned}
$$

Process defect losses adalah produk cacat yang dihasilkan akan mengakibatkan kerugian material, mengurangi jumlah produksi, limbah produksi meningkat dan peningkatan biaya untuk pengerjaan ulang (Limantoro \& Felecia, 2013). Rumus penghitungan untuk process defect losses adalah:

$$
\begin{aligned}
\text { Process defect losses } & =\frac{\text { Ideal cycle time } \times \text { Total process defect }}{\text { Loading time }} \\
& \times 100 \%
\end{aligned}
$$

Reduced yield losses adalah kerugian yang timbul selama waktu yang dibutuhkan oleh mesin untuk menghasilkan produk baru dengan kualitas produk yang diharapkan. Kerugian yang timbul bergantung pada faktor seperti kondisi operasi yang tidak stabil, tidak tepatnya penanganan dan pemasangan peralatan ataupun operator tidak mengerti dengan kegiatan produksi yang dilakukan (Limantoro \& Felecia, 2013). Rumus penghitungan untuk reduce yield losses adalah:

$$
\begin{aligned}
\text { Reduced yield losses }= & \frac{\text { Ideal cycle time } \times \text { Total reduced yield }}{\text { Loading time }} \\
& \times 100 \% \quad \text { (Pers.10) }
\end{aligned}
$$

\section{Fault Tree Analysis (FTA)}

Fault Tree Analysis (FTA) merupakan suatu teknik analisis kegagalan deduktif yang menyediakan metode untuk menentukan penyebab dari suatu peristiwa tertentu yang tidak diinginkan (U.S. Nuclear Regulatory Commission, 1981).

Berbeda dengan metode Seven Tools yang menggunakan pendekatan kuantitatif melalui 7 alat grafis maka metode Fault Tree Analysis (FTA) adalah suatu teknik yang digunakan untuk mengidentifikasi resiko yang berperan terhadap terjadinya kegagalan. Metode ini dilakukan dengan pendekatan yang bersifat top down, yang diawali dengan asumsi kegagalan atau kerugian dari kejadian puncak (Top Event) kemudian merinci sebab-sebab suatu Top Event sampai pada suatu kegagalan dasar (root cause).
Fault Tree Analysis (FTA) dilakukan dengan mengikuti langkah-langkah berikut ini (NASA, 2002):

1. Mengidentifikasi tujuan untuk FTA

2. Menentukan top event dari FT

3. Menentukan ruang lingkup dari FTA

4. Menentukan resolusi dari FTA

5. Menentukan aturan dasar untuk FTA

6. Membangun FT

7. Mengevaluasi FT

8. Menginterprestasikan dan mempresentasikan hasil

\section{Hasil dan Pembahasan \\ 1. Hasil Perhitungan OEE}

Hasil perhitungan nilai OEE mesin reng pada periode 11 April 2016 - 30 Juni 2016 (12 minggu) dapat dilihat pada tabel 1 .

Nilai availability mesin reng berada di antara nilai $77,81 \%$ hingga $81,97 \%$ dengan rata-rata $80,40 \%$, dan secara keseluruhan masih berada di bawah nilai availability ideal (90\%). Dalam hal ini, mesin reng masih mengalami breakdown dan waktu setup dan adjustment yang lama, sehingga masih memungkinkan untuk meningkatkan nilai availability dengan cara menganalisis dan memperbaiki faktor breakdown losses dan setup and adjustment losses mesin reng.

Nilai performance efficiency mesin reng berada diantara nilai $75,93 \%$ hingga $81,07 \%$ dengan rata-rata $78,29 \%$, dan secara keseluruhan masih berada di bawah nilai performance efficiency ideal (95\%). Dalam hal ini, mesin reng belum bekerja sesuai dengan kecepatan yang ditetapkan perusahaan, sehingga masih memungkinkan untuk meningkatkan nilai performance efficiency dengan cara menganalisis dan memperbaiki faktor idling and minor stoppage losses dan reduced speed losses mesin reng.

Nilai rate of quality products mesin reng berada diantara nilai $90,68 \%$ hingga $91,67 \%$ dengan rata-rata $91,42 \%$, dan secara keseluruhan masih berada di bawah nilai rate of quality products ideal (99\%). Dalam hal ini, mesin reng masih menghasilkan produk di luar spesifikasi perusahaan, sehingga masih memungkinkan untuk meningkatkan nilai rate of quality products dengan cara menganalisis dan memperbaiki faktor process defect losses dan reduced yield losses mesin reng. 
Tabel 1. Overall Equipment Effectiveness Mesin Reng Periode 11 April 2016 - 30 Juni 2016

\begin{tabular}{ccccc} 
Weeks & $\begin{array}{c}\text { Availability } \\
\text { Ratio }(\%)\end{array}$ & $\begin{array}{c}\text { Performance } \\
\text { Efficiency }(\%)\end{array}$ & $\begin{array}{c}\text { Rate of } \\
\text { Quality }(\%)\end{array}$ & $\begin{array}{c}\text { OEE } \\
(\%)\end{array}$ \\
\hline 1 & 79,83 & 76,94 & 91,53 & 56,22 \\
2 & 79,32 & 81,07 & 92,32 & 59,37 \\
3 & 80,60 & 78,32 & 91,37 & 57,67 \\
4 & 81,53 & 77,15 & 90,84 & 57,14 \\
5 & 80,70 & 78,16 & 91,56 & 57,75 \\
6 & 77,81 & 75,97 & 91,63 & 54,16 \\
7 & 80,51 & 79,61 & 91,58 & 58,69 \\
8 & 81,86 & 77,33 & 91,09 & 57,67 \\
9 & 78,39 & 77,64 & 90,68 & 55,18 \\
10 & 81,90 & 80,41 & 90,97 & 59,91 \\
11 & 81,48 & 79,80 & 91,67 & 59,60 \\
12 & 81,97 & 75,93 & 91,60 & 57,02 \\
Rata-rata & $\mathbf{8 0 , 4 0}$ & $\mathbf{7 8 , 2 9}$ & $\mathbf{9 1 , 4 2}$ & $\mathbf{5 7 , 5 5}$
\end{tabular}

Nilai OEE mesin berada di antara nilai $54,16 \%$ hingga $59,91 \%$ dengan rata-rata $57,55 \%$, dan secara keseluruhan masih berada di bawah nilai OEE ideal (85\%). Dalam hal ini, perusahaan (CV. Ali Griya) memiliki ruang yang besar untuk melakukan improvement untuk meningkatkan nilai OEE dengan cara meningkatkan nilai availability, performance efficiency, dan rate of quality products.

\section{Hasil Perhitungan Six Big Losses}

Hasil perhitungan six big losses mesin reng pada periode 11 April 2016 - 30 Juni 2016 (12 minggu) dapat dilihat pada tabel 2 .

Jumlah waktu yang hilang (total time losses) selama proses produksi mesin reng pada periode 11 April 2016 - 30 Juni 2016 adalah sebesar 188,19 jam (42,45\% terhadap loading time). Setup and adjustment losses memiliki kontribusi terbesar dengan persentase sebesar 43,69\% (82,22 jam), dan diikuti oleh idling and minor stoppage losses sebesar 31,23\% (58,76 jam), process defect losses sebesar 10,56\% (19,88 jam), reduced speed losses sebesar 9,88\% (18,60 jam), breakdown losses sebesar 2,48\% (4,67 jam), dan reduced yield losses yang memiliki kontribusi terkecil sebesar 2,16\% (4,06 jam).

\section{Fault Tree Analysis (FTA)}

\section{a. Setup and Adjustment Losses Mesin Reng}

Setup and adjustment losses adalah kerugian yang diakibatkan oleh lamanya waktu setup. Ada 3 jenis bentuk kerugian yang menyebabkan setup and adjustment losses mesin reng, yaitu proses setting roll lama, proses setting meja cutter lama, dan proses setup bahan baku/ coil lama.

Proses setting roll lama disebabkan karena operator kurang fokus saat melakukan setting roll atau karena metode setting roll salah. Penyebab operator kurang fokus adalah karena operator sudah jenuh, atau karena lantai produksi tidak nyaman. Penyebab metode setting roll salah adalah karena operator kurang paham mengenai bagian, bentuk roll, dan fungsinya, atau karena operator kurang paham bagaimana cara setting roll yang benar.

Proses setting meja cutter lama disebabkan karena operator kurang fokus saat setting meja cutter, atau karena metode setting meja cutter salah. Penyebab operator kurang fokus adalah karena operator sudah jenuh, atau karena lantai produksi tidak nyaman. Penyebab metode setting meja cutter salah adalah karena operator kurang paham bagian meja cutter dan fungsinya, atau karena operator kurang paham cara setting meja cutter yang benar.

Proses set up bahan baku/ uncoil lama disebabkan karena proses pemindahan bahan baku/ coil lama, atau karena proses pemasangan coil ke penyangga coil lama. Penyebab proses pemindahan bahan baku lama adalah karena jarak tempat bahan baku/ coil ke penyangga coil jauh, atau karena jumlah hand pallet truck terbatas. Penyebab proses pemasangan coil ke penyangga coil lama adalah karena jumlah manual stacker terbatas, atau karena operator kurang paham cara memasang coil. Fault Tree setup and adjustment losses mesin reng dapat dilihat pada gambar 1 .

\section{b. Idling and Minor Stoppage Losses Mesin Reng}

Idling and minor stoppage losses terjadi ketika produksi terganggu oleh kegagalan fungsi/ kerusakan yang bersifat sementara atau ketika mesin sedang menganggur. Ada 2 jenis bentuk kerugian yang menyebabkan idling and minor stoppage losses mesin reng, yaitu setting roll tidak pas, dan setting meja cutter tidak pas.

Penyebab setting roll tidak pas adalah karena posisi as roll berubah secara horizontal, posisi as roll berubah secara vertikal, atau karena operator kurang paham cara 
setting roll. Penyebab posisi as roll berubah secara horizontal adalah karena mur as roll kendor, dan disertai dengan adanya getaran mesin yang tinggi. Kendornya mur as roll disebabkan karena penguncian mur as tidak benar, dan disertai dengan adanya faktor getaran mesin yang tinggi. Sedangkan, penyebab posisi as roll berubah secara vertikal adalah karena mur penyangga as roll kendor, atau karena putaran gear as tidak normal. Kendornya mur tersebut disebabkan karena penguncian mur penyangga as tidak benar, dan disertai dengan adanya getaran mesin yang tinggi. Penyebab putaran gear as tidak normal adalah karena mur setting gear as kendor, atau karena bearing pecah. Faktor yang menyebabkan mur setting gear as kendor adalah karena penguncian mur gear as tidak benar, dan disertai dengan adanya getaran mesin yang tinggi.

Setting meja cutter tidak pas disebabkan oleh karena posisi meja cutter berubah secara horizontal, secara vertikal, atau karena operator kurang paham cara setting meja cutter yang benar. Perubahan posisi meja cutter secara horizontal yaitu terjadi pergeseran meja cutter ke kiri atau ke kanan, yang disebabkan karena mur meja cutter kendor, dan disertai dengan adanya getaran mesin yang tinggi. Mur meja cutter yang kendor disebabkan oleh karena penguncian mur meja cutter tidak benar, dan disertai dengan adanya getaran mesin yang tinggi. Sedangkan perubahan posisi meja cutter secara vertikal yaitu terjadinya kenaikan atau penurunan posisi meja cutter ke atas atau ke bawah, yang disebabkan karena mur penyangga meja cutter kendor, dan disertai dengan adanya getaran mesin yang tinggi. Faktor penyebab mur penyangga meja cutter kendor adalah karena penguncian mur penyangga meja cutter tidak benar, dan disertai dengan adanya getaran mesin yang tinggi. Fault Tree idling and minor stoppage losses mesin reng dapat dilihat pada gambar 2.

\section{c. Process Defect Losses Mesin Reng}

Process defect losses adalah kerugian yang terjadi karena disebabkan oleh adanya produk yang cacat selama produksi rutin. Ada 3 jenis bentuk kerugian dari process defect losses mesin reng, yaitu lipatan sayap terbuka, produk tidak sesuai dengan spesifiksai ukuran, dan hasil cutting tidak rata.

Faktor yang menyebabkan lipatan sayap terbuka adalah karena setting jarak antara pasangan roll 5, 6, dan 7 tidak pas, atau karena coil/material tidak bagus.

Tabel 2 Persentase Six Big Losses Mesin Reng Periode 11 April 2016 - 30 Juni 2016

\begin{tabular}{|c|c|c|c|c|c|}
\hline No & Six Big Losses & $\begin{array}{l}\text { Total Time } \\
\text { Losses (h) }\end{array}$ & $\begin{array}{l}\text { Persentase } \\
\text { terhadap } \\
\text { Loading } \\
\text { Time }(\%)\end{array}$ & $\begin{array}{l}\text { Persentase } \\
\text { terhadap } \\
\text { Total Time } \\
\text { Losses }(\%)\end{array}$ & $\begin{array}{l}\text { Persentase } \\
\text { Kumulatif } \\
\quad(\%)\end{array}$ \\
\hline 1 & \multirow{2}{*}{$\begin{array}{l}\text { Setup and Adjustment } \\
\text { Losses } \\
\text { Idling and Minor } \\
\text { Stoppages Losses }\end{array}$} & 82,22 & 18,55 & 43,69 & 43,69 \\
\hline 2 & & 58,76 & 13,26 & 31,23 & 74,91 \\
\hline 3 & \multirow{3}{*}{$\begin{array}{l}\text { Process Defect Losses } \\
\text { Reduced Speed Losses } \\
\text { Breakdown Losses }\end{array}$} & 19,88 & 4,48 & 10,56 & 85,48 \\
\hline 4 & & 18,60 & 4,20 & 9,88 & 95,36 \\
\hline 5 & & 4,67 & 1,05 & 2,48 & 97,84 \\
\hline 6 & \multirow[t]{2}{*}{ Reduced Yield Losses } & 4,06 & 0,92 & 2,16 & 100,00 \\
\hline Total & & 188,19 & 42,45 & 100,00 & \\
\hline
\end{tabular}




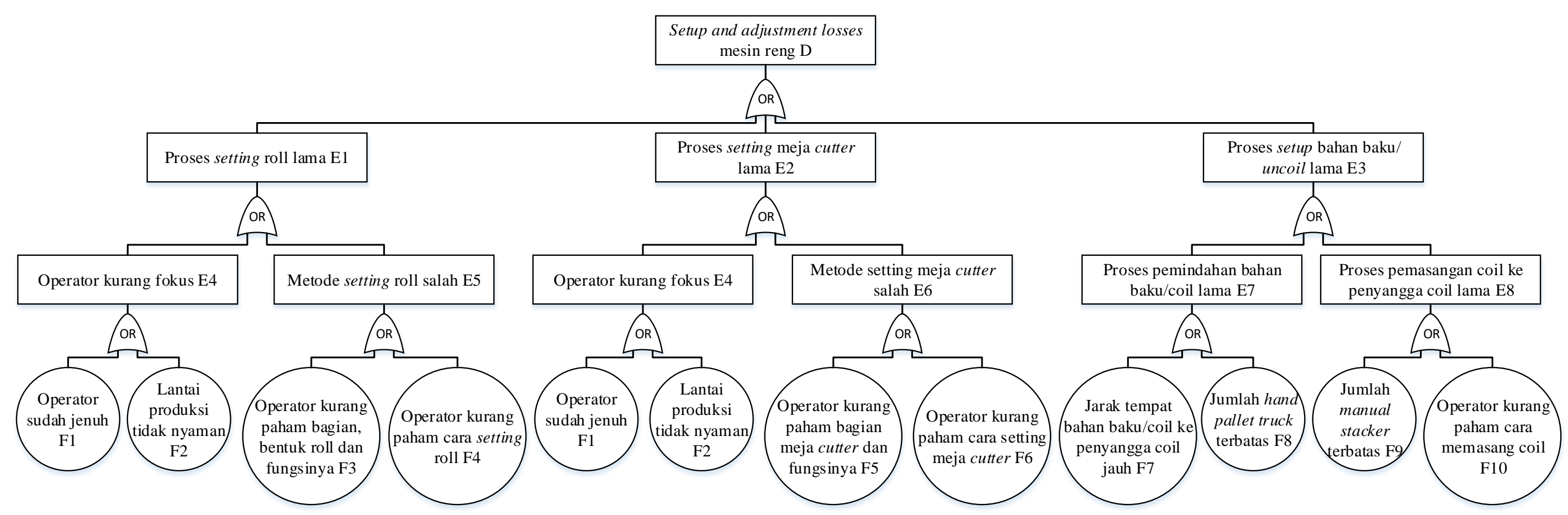

Gambar 1. Fault Tree Setup and Adjustment Losses Mesin Reng 


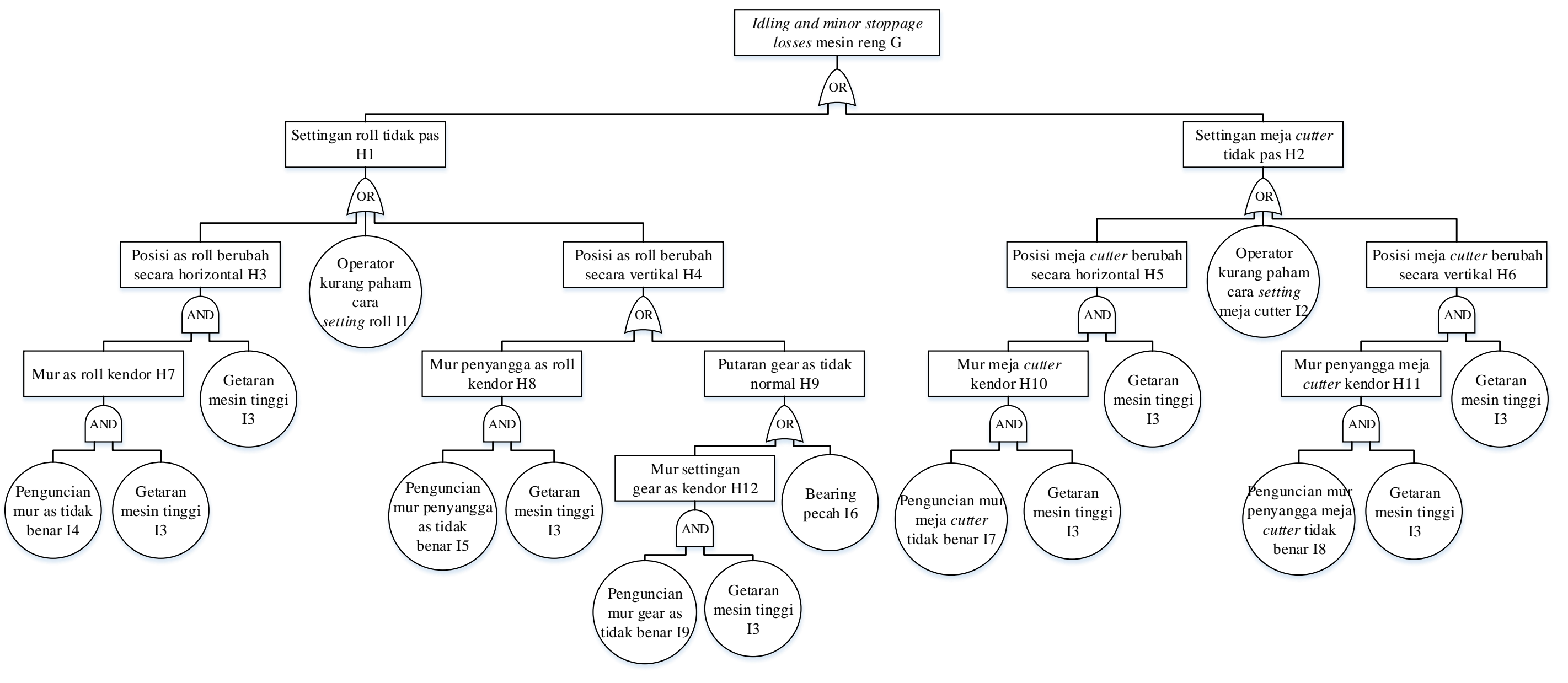

Gambar 2. Fault Tree Idling and Minor Stoppage Losses Mesin Reng 
Setting jarak antara pasangan roll 5, 6, dan 7 tidak pas disebabkan oleh karena mur peyangga as roll kendor, atau karena operator kurang paham cara setting roll. Penyebab mur penyangga as roll kendor adalah karena penguncian mur penyangga as tidak benar, dan disertai dengan adanya getaran mesin yang tinggi.

Produk tidak sesuai dengan spesifikasi ukuran disebabkan oleh karena setting roll tidak pas, atau karena setting meja cutter tidak pas.

Penyebab setting roll tidak pas adalah karena posisi as roll berubah secara horizontal, posisi as roll berubah secara vertikal, atau karena operator kurang paham cara setting roll. Penyebab posisi as roll berubah secara horizontal adalah karena mur as roll kendor, dan disertai dengan adanya getaran mesin yang tinggi. Kendornya mur as roll disebabkan karena penguncian mur as tidak benar, dan disertai dengan adanya faktor getaran mesin yang tinggi.

Sedangkan, penyebab posisi as roll berubah secara vertikal adalah karena mur penyangga as roll kendor, atau karena putaran gear as tidak normal. Kendornya mur tersebut disebabkan karena penguncian mur penyangga as tidak benar, dan disertai dengan adanya getaran mesin yang tinggi. Penyebab putaran gear as tidak normal adalah karena mur settingan gear as kendor, atau karena bearing pecah. Faktor yang menyebabkan mur setting gear as kendor adalah karena penguncian mur gear as tidak benar, dan disertai dengan adanya getaran mesin yang tinggi.

Setting meja cutter tidak pas disebabkan oleh karena posisi meja cutter berubah secara horizontal, secara vertikal, atau karena operator kurang paham cara setting meja cutter yang benar. Perubahan posisi meja cutter secara horizontal yaitu terjadi pergeseran meja cutter ke kiri atau ke kanan, yang disebabkan karena mur meja cutter kendor, dan disertai dengan adanya getaran mesin yang tinggi. Mur meja cutter yang kendor disebabkan oleh karena penguncian mur meja cutter tidak benar, dan disertai dengan adanya getaran mesin yang tinggi. Sedangkan perubahan posisi meja cutter secara vertikal yaitu terjadinya kenaikan atau penurunan posisi meja cutter ke atas atau ke bawah, yang disebabkan karena mur penyangga meja cutter kendor, dan disertai dengan adanya getaran mesin yang tinggi. Faktor penyebab mur penyangga meja cutter kendor adalah karena penguncian mur penyangga meja cutter tidak benar, dan disertai dengan adanya getaran mesin yang tinggi.

Penyebab hasil cutting tidak rata adalah karena cutter tumpul, atau karena coill material tidak bagus. Faktor yang menyebabkan cutter tumpul adalah karena usia komponen cutter sudah lama, atau karena gesekan saat pemotongan tinggi. Penyebab gesekan saat pemotongan tinggi adalah karena cutter jarang diberi oli, atau karena lapisan geram menempel pada cutter Fault Tree process defect losses mesin reng dapat dilihat pada gambar 3.

\section{d. Reduced Speed Losses Mesin Reng}

Reduced speed losses adalah kerugian yang disebabkan oleh penurunan kecepatan peralatan. Ada 4 jenis bentuk kerugian yang menyebabkan reduced speed losses mesin reng, yaitu gesekan antara roll dengan coil tinggi, kecepatan putaran dinamo berkurang, putaran bearing tidak normal, dan gesekan antara roda gigi dan chain tinggi.

Gesekan antara roll dengan coil tinggi disebabkan oleh karena jarak antar roll terlalu dekat, atau karena permukaan roll kotor. Faktor yang menyebabkan jarak antar roll terlalu dekat adalah karena operator kurang paham allowance jarak antar roll, atau karena operator kurang paham cara setting roll. Penyebab roll kotor adalah karena roll jarang dibersihkan, dan disertai dengan adanya sisa perekat dan lapisan $\mathrm{Zn}$ dari coil menempel di roll.

Faktor penyebab kecepatan putaran dinamo berkurang adalah karena usia pemakaian dinamo sudah lama, atau karena kondisi dinamo kurang terawat. Putaran bearing tidak normal disebabkan karena usia komponen bearing sudah lama, atau karena bearing jarang diberi oli. Sedangkan gesekan antara roda gigi dan chain tinggi disebabkan oleh karena roda gigi jarang diberi oli, dan karena chain juga jarang diberi oli. Fault Tree reduced speed losses mesin reng dapat dilihat pada gambar 4.

\section{e. Breakdown Losses Mesin Reng}

Breakdown Losses merupakan kerugian yang disebabkan oleh kegagalan part (komponen) di mana tidak dapat bekerja lagi dan perlu diperbaiki atau diganti. Ada 2 jenis bentuk kerugian yang menyebabkan breakdown losses mesin reng, yaitu permukaan roll rusak, dan cutter tumpul.

Permukaan roll rusak disebabkan oleh karena usia komponen roll sudah lama, coil/ material tidak bagus, atau karena gesekan antara roll dengan coil tinggi. Penyebab gesekan yang tinggi antara roll dengan coil adalah karena jarak antar roll terlalu dekat, atau karena permukaan roll kotor.

Faktor yang dapat menyebabkan jarak antar roll terlalu dekat adalah karena operator kurang paham allowance jarak antar roll, atau karena operator kurang paham cara setting roll. Sedangkan penyebab permukaan roll kotor adalah karena roll jarang dibersihkan, dan karena sisa perekat dan lapisan $\mathrm{Zn}$ dari coil menempel di roll. 


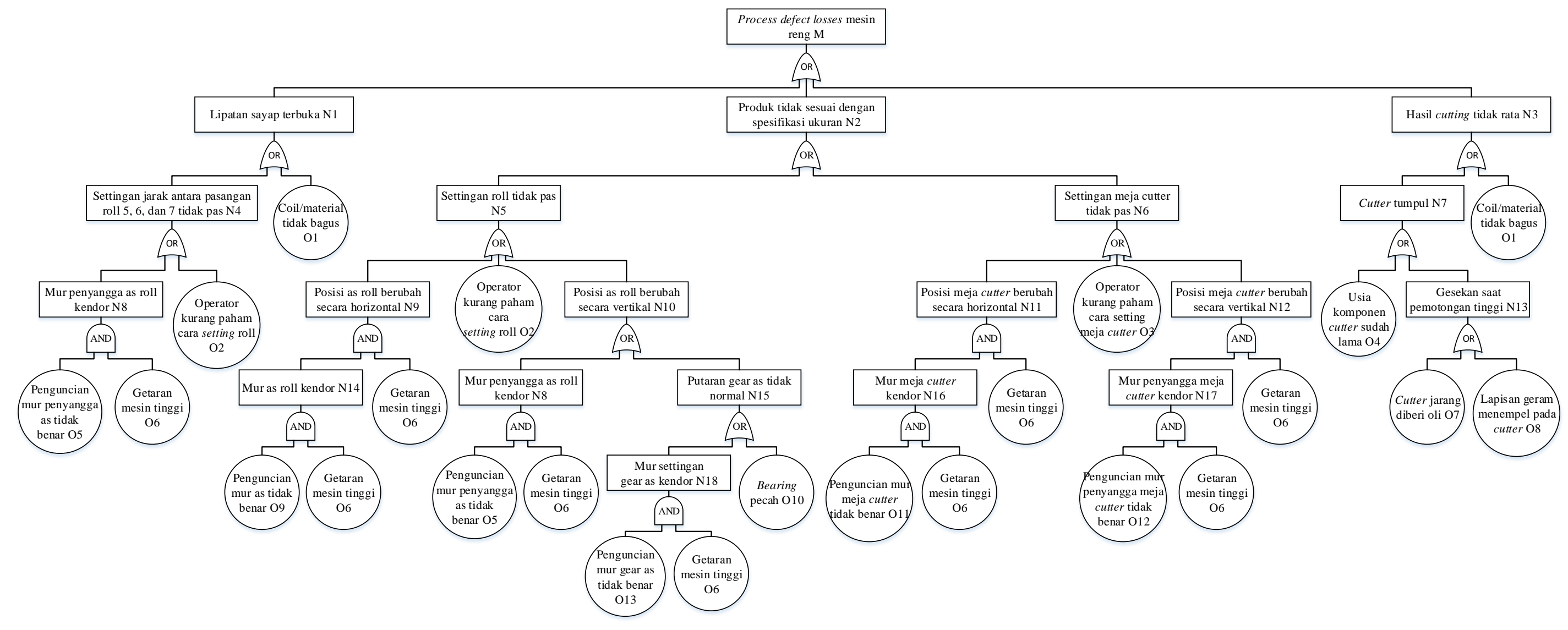

Gambar 3. Fault Tree Process Defect Losses Mesin Reng 


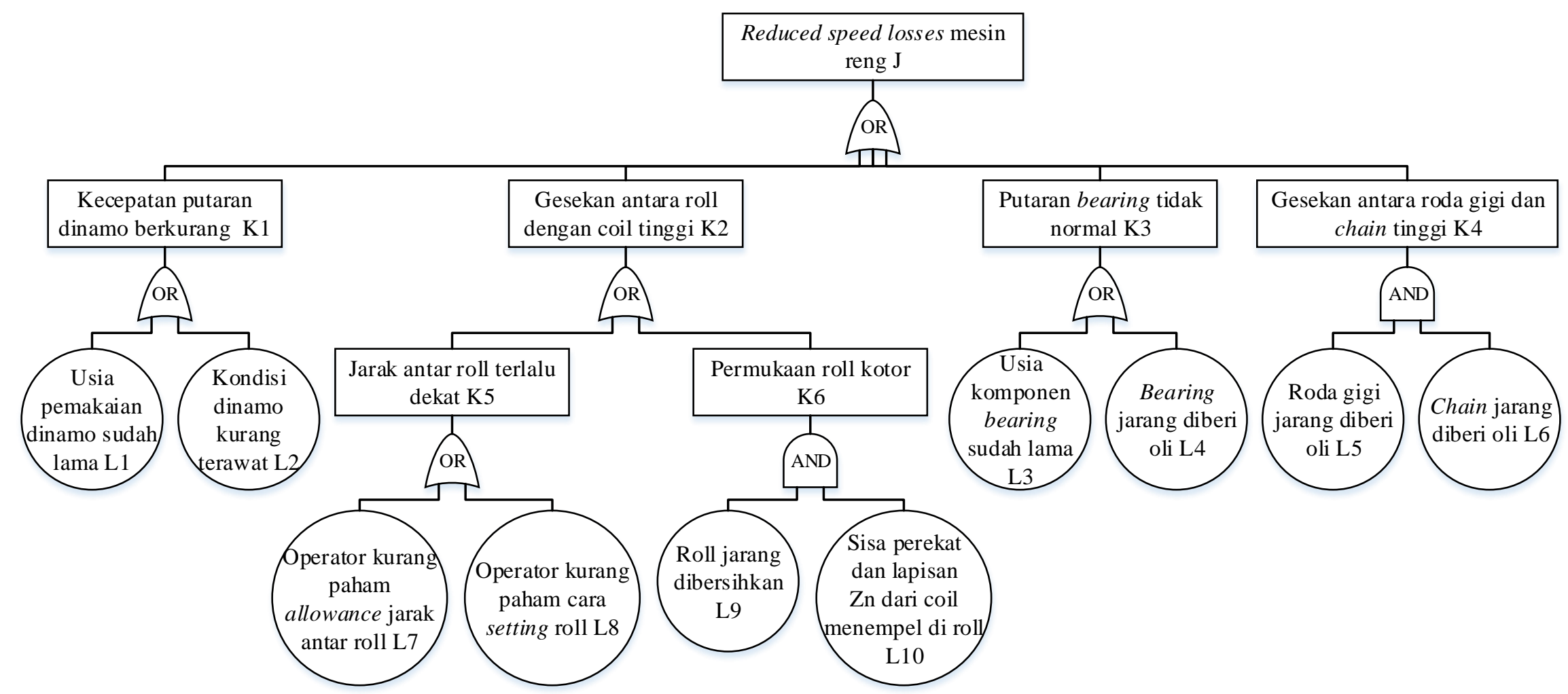

Gambar 4. Fault Tree Reduced Speed Losses Mesin Reng 
Cutter tumpul disebabkan oleh karena usia komponen cutter sudah lama, atau karena gesekan saat pemotongan tinggi. Penyebab gesekan saat pemotongan tinggi adalah karena cutter jarang diberi oli, atau karena lapisan geram menempel pada cutter. Fault Tree breakdown losses mesin reng dapat dilihat pada gambar 5. Adanya potongan produk hasil proses setup awal mesin, dan adanya potongan produk hasil proses adjustment mesin disebabkan oleh karena setting roll belum sesuai, atau karena setting meja cutter belum sesuai. Faktor yang menyebabkan setting roll belum sesuai adalah karena operator kurang paham bentuk, bagian, dan fungsi roll, atau karena operator kurang paham cara setting roll. Faktor yang menyebabkan setting meja cutter belum sesuai adalah karena operator kurang paham bagian meja cutter dan fungsinya, atau karena operator kurang paham cara setting meja cutter.

Faktor yang menyebabkan adanya potongan produk sisa di akhir produksi adalah karena adanya potongan produk hasil setup awal mesin reng, atau karena adanya potongan produk hasil adjustment mesin reng. Fault Tree reduced yield losses mesin reng dapat dilihat pada gambar 6 .

\subsection{Rekomendasi Perbaikan}

Rekomendasi perbaikan yang dirancang untuk meningkatkan tingkat efektivitas mesin reng, diantaranya:

1. Eliminasi six big losses mesin reng melalui rekomendasi perbaikan yang diberikan terhadap penyebab dasar dari masing-masing six big losses, yang terdiri setup and adjustment losses (meliputi: melakukan rotasi pekerjaan, menyediakan fasilitas dan kondisi tempat kerja yang nyaman, pemasangan exhaust fan, membersihkan lantai produksi, pelatihan tentang jenis roll, pelatihan setting roll, penyediaan buku panduan mesin, pelatihan tentang cutter, mengatur jarak coil, mengatur pemakaian hand pallet truck, menambah jumlah manual stacker, pelatihan tentang pemasangan coil), idling and minor stoppage losses (meliputi: pelatihan tentang setting roll, menyediakan buku panduan mesin, pelatihan tentang setting meja cutter, pemeriksaan berkala semua mur, mengganti bearing yang pecah), process defect losses (meliputi: memilih supplier yang tepat, pelatihan tentang setting roll, pelatihan setting meja cutter, menyediakan buku panduan mesin, memeriksa usia pakai cutter, memasang dan mengunci mur dengan benar, memeriksa kondisi oli cutter, pembersihan berkala cutter, mengganti bearing yang pecah), reduced speed losses (meliputi: memeriksa atau mengganti dinamo, pembersihan berkala dinamo, memeriksa atau mengganti bearing yang rusak, pemeberian berkala oli bearing, oli roda gigi, oli rantai, pelatihan allowance jarak pasangan roll, pelatihan setting roll, pembersihan berkala roll, mebersihkan plester perekat roll), breakdown losses (meliputi: memeriksa atau mengganti roll, memilih supplier coil yang sesuai, memeriksa atau mengganti cutter, pemberian berkala oli cutter, pembersihan berkala cutter, pelatihan allowance jarak roll, pelatihan setting roll, menyediakan buku panduan mesin, pembersihan berkala roll, membersihkan plester perekat coil), reduced yield losses (meliputi: kemampuan yang baik dalamsetup awal, kemampuan yang baik dalam melakukan adjustment mesin, pelatihan jenis roll, menyediakan buku panduan mesin, pelatihan cara setting roll, pelatihan tentang bagian meja cutter dan cara setting yang benar).

2. Mengembangkan program pemeliharaaan untuk menjaga dan mempertahankan agar mesin tetap berada pada kondisi terbaiknya. Terdapat beberapa kegiatan pemeliharaaan harian yang terdiri dari pemeriksaan (meliputi: mur, roll, setting roll, cutter, gear, rantai, penutup oli gearbox), pembersihan (meliputi: roll, cutter, meja cutter, gear, chain, gearbox), pelumasan (meliputi: cutter, gear, chain), dan kegiatan pemeliharaan mingguan (meliputi: pemeliharaan mur dan baut pengunci pada chasis, gearbox, dinamo, dan hidrolik cutter), dan untuk memudahkan pelaksanaannya, program pemeliharaan didukung dengan penggunaan checklist pemeliharaan harian dan mingguan.

3. Meningkatkan kemampuan pengoperasian dan pemeliharaan mesin dengan cara melakukan pelatihan kepada semua operator mesin dengan garis-garis besar program pelatihan yang terdiri dari pengembangan materi (meliputi: materi pengenalan mesin reng, dan bagiannya, cara setting mesin, cara pengoperasian, dan pemeliharaan mesin reng), strategi penerapan (meliputi: metode, peserta, tempat dan jadwal pelatihan, narasumber, peralatan dan prasarana), pelaksanaan program pelatihan (meliputi: persiapan bahan dan peralatan, pelaksanaan teknis, simulasi, praktik, dan diskusi), evaluasi dan pengukuran hasil penerapan (meliputi: pengukuran parameter dan kriteria, membuat level kemampuan).

\section{Kesimpulan}

Berdasarkan analisis dan pembahasan yang telah dilakukan, dapat disimpulkan bahwa tingkat efektivitas (OEE) mesin reng pada periode 11 April 2016 - 30 Juni 2016 berada diantara nilai 54,16\% hingga 59,91\% dengan rata-rata $57,55 \%$ (masih berada di bawah nilai OEE ideal 85\%) dengan persentase six big losses sebesar $42,45 \%$. 


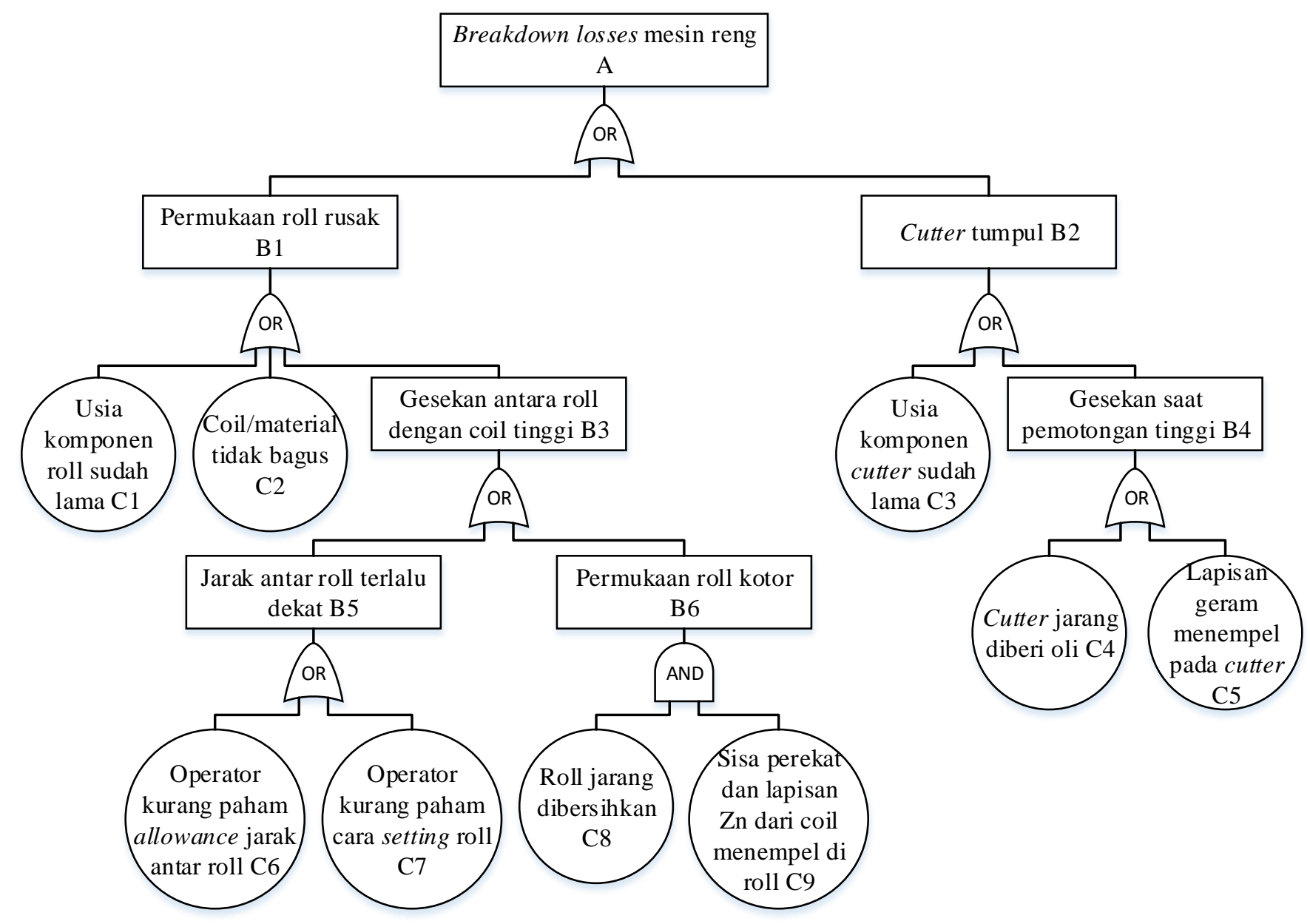

Gambar 5. Fault Tree Breakdown Losses Mesin Reng 


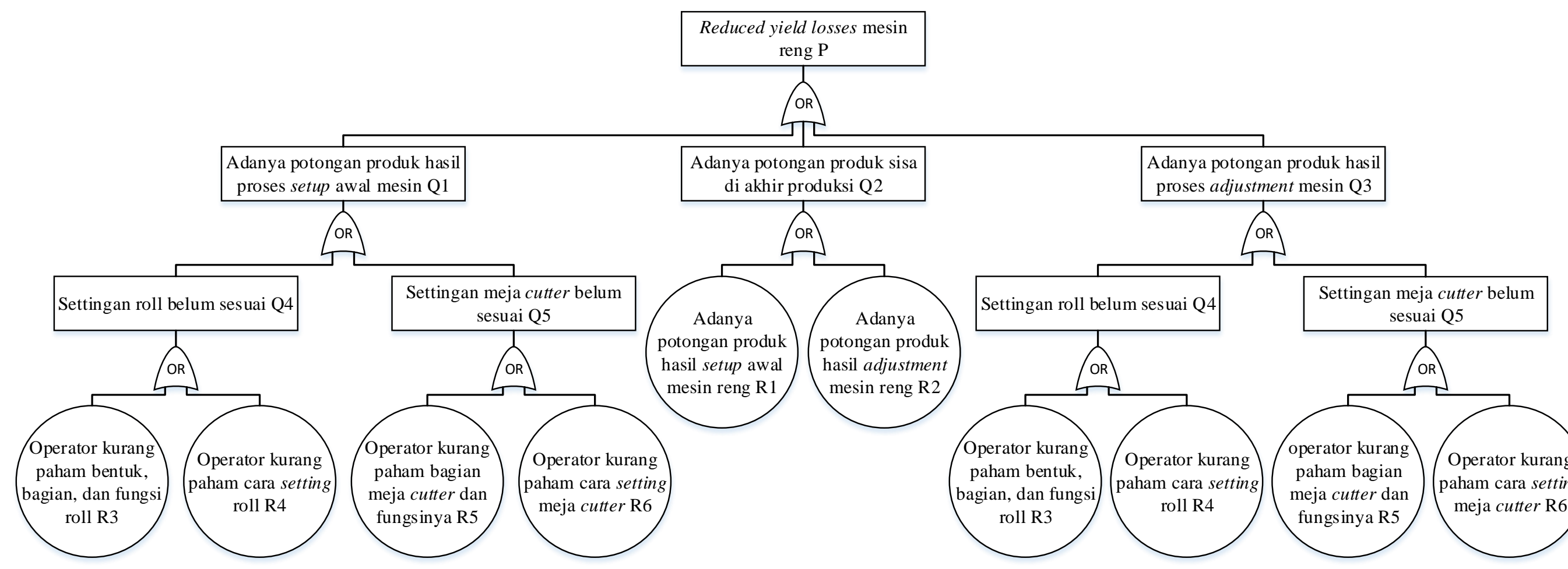

Gambar 6. Fault Tree Reduced Yield Losses Mesin Reng 
Faktor-faktor penyebab six big losses mesin reng, antara lain faktor penyebab setup and adjustment losses, yaitu operator sudah jenuh, lantai produksi tidak nyaman, operator kurang paham bagian, bentuk roll dan fungsinya, operator kurang paham cara setting roll, operator kurang paham bagian meja cutter dan fungsinya, operator kurang paham cara setting meja cutter, jarak tempat bahan baku/ coil ke penyangga coil jauh, jumlah hand pallet truck terbatas, jumlah manual stacker terbatas, operator kurang paham cara memasang coil. Faktor penyebab idling and minor stoppage losses, yaitu operator kurang paham cara setting roll, operator kurang paham cara setting meja cutter, getaran mesin tinggi, penguncian mur as tidak benar, penguncian mur penyangga as tidak benar, bearing pecah, penguncian mur meja cutter tidak benar, penguncian mur penyangga meja cutter tidak benar, penguncian mur gear as tidak benar. Faktor penyebab process defect losses, yaitu coil/ material tidak bagus, operator kurang paham cara setting roll, operator kurang paham cara setting meja cutter, usia komponen cutter sudah lama, penguncian mur penyangga as tidak benar, getaran mesin tinggi, cutter jarang diberi oli, lapisan geram menempel pada cutter, penguncian mur as tidak benar, bearing pecah, penguncian mur meja cutter tidak benar, penguncian mur penyangga meja cutter tidak benar, penguncian mur gear as tidak benar. Faktor penyebab reduced speed losses, yaitu usia pemakaian dinamo sudah lama, kondisi dinamo kurang terawat, usia komponen bearing sudah lama, bearing jarang diberi oli, roda gigi jarang diberi oli, chain jarang diberi oli, operator kurang paham allowance jarak antar roll, operator kurang paham cara setting roll, roll jarang dibersihkan, sisa perekat dan lapisan $\mathrm{Zn}$ dari coil menempel di roll. Faktor penyebab breakdown losses, yaitu usia komponen roll sudah lama, coil/ material tidak bagus, usia komponen cutter sudah lama, cutter jarang diberi oli, lapisan geram menempel pada cutter, operator kurang paham allowance jarak antar roll, operator kurang paham cara setting roll, roll jarang dibersihkan, sisa perekat dan lapisan $\mathrm{Zn}$ dari coil menempel di roll. Faktor penyebab reduced yield losses, yaitu adanya potongan produk hasil setup awal mesin reng, adanya potongan produk hasil adjustment mesin reng, operator kurang paham bentuk, bagian, dan fungsi roll, operator kurang paham cara setting roll, operator kurang paham bagian meja cutter dan fungsinya, operator kurang paham cara setting meja cutter.

Rekomendasi perbaikan yang diberikan untuk meningkatkan tingkat efektivitas mesin reng yaitu eliminasi six big losses mesin reng melalui perbaikan yang diberikan terhadap penyebab dasar dari masingmasing six big losses, mengembangkan program pemeliharaaan untuk menjaga dan mempertahankan agar mesin tetap berada pada kondisi terbaiknya., dan meningkatkan kemampuan pengoperasian dan pemeliharaan mesin dengan cara melakukan pelatihan kepada semua operator mesin.
Kelemahan penelitian ini adalah kemungkinan kegagalan dasar (root cause) tidak semua terindentifikasi. Hal ini disebabkan karena identifikasi kegagalan tersebut dilakukan dengan asumsi bahwa kegagalan atau kerugian dasar (root cause) diawali dari adanya kejadian puncak (Top Event) terlebih dahulu. Padahal tidak ada jaminan bahwa semua kejadian awal sudah teridentifikasi. Untuk mengatasi kelemahan penelitian ini maka pada penelitian selanjutnya perlu dilakukan studi sensitivitas, penggunaan keputusan ahli (expert judgement) dan peer review.

\section{Daftar Pustaka}

Almeanazel, O. T. (2010). Total Productive Maintenance Review and Overall Equipment Effectiveness Measurement. Jordan Journal of Mechanical and Industrial Engineering.

Limantoro, D., \& Felecia. (2013). Total Productive Maintenance di PT. X. Jurnal Titra Vol. 1 No. 1, 13-20.

Nakajima, S. (1988). Introduction to TPM (Total Productive Maintenance). Cambridge: Productivity Press, Inc.

NASA. (2002). Fault Tree Handbook with Aerospace Applications. Washington, D.C.: NASA Office of Safety and Mission Assurance.

Saiful, Rapi, A., \& Novawanda, O. (2014). Pengukuran Kinerja Mesin Defekator I dengan Menggunakan Metode Overall Equipment Effectiveness (Studi Kasus pada PT. Perkebunan XY). 2.

U.S. Nuclear Regulatory Commission. (1981). NUREG - 0492: Fault Tree Handbook. Washington, D.C: U.S. Nuclear Regulatory Commission. 